\title{
SMEs and knowledge-capital formation in innovation networks: a review of literature
}

\author{
Blandine Laperche ${ }^{*}$ and Zeting Liu
}

\author{
* Correspondence: \\ blandine.laperche@univ-littoral.fr \\ CLERSE UMR 8019, Université du \\ Littoral Côté d'Opale, Dunkerque \\ 59140, France
}

\begin{abstract}
To innovate, firms constitute a 'knowledge-capital', defined as a set of information and knowledge produced, acquired and used in the value creation process. In this paper, we focus on small and medium-sized companies (SMEs) and study their ability to develop their own knowledge-capital as well as their role in the formation of larger companies' ones. We show that while the ability of SMEs to build a strong knowledge-capital remains weak (mainly due to fewer resources), SMEs play an important role in the continuous enrichment of larger companies' ones. At the same time, their strength within larger firms' innovation networks largely depends on their ability to develop and reinforce their own knowledge-capital.

JEL: L20; O32; 030

Keywords: Knowledge-capital; SMEs; Absorptive capacity; Open innovation; Networks
\end{abstract}

\section{Review}

Introduction

To innovate, firms constitute a 'knowledge-capital', defined as a set of information and knowledge produced, acquired and used in the value creation process. In a context of global competition, the development of a firm's knowledge-capital mostly relies on the cooperation that the firm may establish with other large and small companies and/or with other organizations like institutions of academic research and institutions supporting innovation. The construction of the knowledge-capital thus takes place into innovation networks.

The issue of the construction of a firm's knowledge-capital, integrating the creation of absorptive capacities and the development of open innovation strategy is mainly studied for big companies (Lee et al. 2010; Spithoven et al. 2010; Parida et al. 2012). Due to fewer human and financial resources, small and medium-sized companies (SMEs; defined as an individual company with no more than 250 employees and a turnover that does not exceed 50 million euros or 43 million euros balance sheet according to the European Commission) usually record weak performances in terms of research and innovation. However, innovation has nowadays become a competitive stake, and both SMEs' place in the productive system of economies (SMEs represent, according to Eurostat, more than $99 \%$ of the total number of companies in Europe) and their role in economic growth and innovation, as stated by many academics since

(C) 2013 Laperche and Liu; licensee Springer. This is an Open Access article distributed under the terms of the Creative Commons Attribution License (http://creativecommons.org/licenses/by/2.0), which permits unrestricted use, distribution, and reproduction in any medium, provided the original work is properly cited. 
the publication work of Schumpeter $(1950,1983)$, justify to study their strategy. Hence, in this paper, we focus on small and medium-sized companies in order to put forward firstly their own strategy of knowledge-capital building and secondly the place and role they play in the constitution of large companies' knowledge-capital. How do SMEs manage to constitute their knowledge-capital? What are their relations with large companies in this matter? To answer these questions, we conducted a literature review (mainly in economics and innovation management) in order to catch the main tendencies of SMEs' behaviours regarding these topical issues in innovation management.

The structure of the paper is as follows. In the first part, we come back to the definition of the concept of knowledge-capital. We put forward its theoretical foundations as well as two major concepts that show its topicality: the development of absorptive capacities and the tendency towards open innovation strategies. In the second part, based on our literature review, we focus on SMEs' strategies of knowledge-capital building, underlining their behaviour and performance in terms of absorptive capacity and of open innovation strategies. In the third part, we show that SMEs play important roles in the innovation networks built by big companies, both in terms of knowledge-capital formation and valorization.

\section{The knowledge-capital: definition and formation}

\section{Definition and theoretical foundations}

We can define knowledge-capital as the set of scientific and technical knowledge and information produced, acquired, combined and systematized by one or several firms for productive purposes (Laperche 2007). Knowledge-capital (see Figure 1) refers to the accumulated knowledge of one or several linked firms (embedded in the individuals know-how - machines, technologies and routines of the enterprise), which is continuously enriched by information flows and which is used in the production process or more globally in the value creation process. Thus, it is a dynamic concept - a process - that defines the knowledge accumulated by one or several firms, continuously enriched and combined in different ways and eventually used or commercialized. This productive aim - the creation of value - is the main characteristic, which turns knowledge into 'capital'.

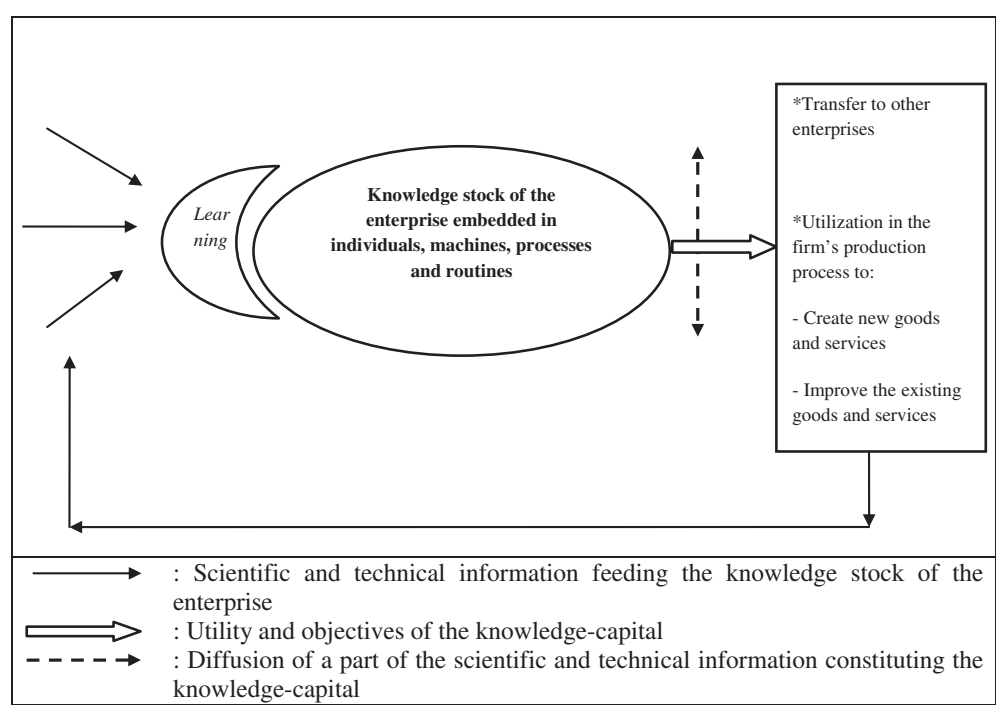

Figure 1 The knowledge-capital. Adapted from Laperche (2007) and Laperche et al. (2011). 
The information collected on markets (through intelligence strategy, access to patent information, purchase of technology, partnerships and signature of licensing contracts, etc.) is integrated into the knowledge stock through learning processes which are basic in the transformation of information (flow) into knowledge (stock). The use of the knowledge stock depends on market and production opportunities and on the degree of maturity of the existing technologies.

A firm may use its knowledge-capital in a value creation process by:

- Simply selling this knowledge base to another enterprise (e.g. the selling of a computer program). Thus, the knowledge-capital (embodied in the software) is transferred to another enterprise, which can use it in its production process.

- Using this knowledge-capital in its own production process. In this case, the knowledge-capital can be considered as a means to produce or to improve goods and services and as a tool for reducing the production process completion time.

Theoretically, the notion of knowledge-capital is based on the definitions and/or on the economic developments of three key concepts/notions: knowledge, firm and capital.

The economic analysis of knowledge has changed over time. Neoclassical economists first considered technical progress as exogenous and knowledge as a public good, notably characterized by its non-appropriability. As for technical progress, the firm has also long been considered as a 'black box' and did not very much catch the contemporary economists' eyes. After the Second World War, the firm has become a complete object of study, place of production of new knowledge (Penrose 1959) and symbol of modern capitalism (Galbraith 1967). The interest that arose not only from the work of Schumpeter $(1950,1983)$ on the role of innovation in economic dynamism but also from that of Solow (1957) on residual technical progress and economic growth gave birth to a new analysis aiming at explaining the origin of innovation and of knowledge. The evolutionist theory and the resource-based approaches stress the learning processes that are at the origin of the firm's routines and of their technological trajectories and put forward the double nature of knowledge, codified and tacit, which makes its appropriability possible (almost in part) (Nelson and Winter 1982; Dosi et al. 2000). The new growth theories have taken account of those new developments and associate public intervention to the market as a place of allocation and appropriation (intellectual property rights, routines) of fundamental resources to growth.

The notion of knowledge-capital is built on these main evolutions in the analysis of knowledge and firm, but it does not forget the crucial contributions of early authors. The developments of classical economists already stressed the collective nature of production and of innovation. Smith (1976) considered the technical and social division of labour as a means to increase the productive and innovative power of labour. Say (1996) analyzed the links between the scientist, the entrepreneur and the worker. Marx (1977) showed how production is based on the combined workforce - appropriated by capital - of the collective of workers. The notion of knowledge-capital also borrows from the classical economists' dynamic conception of capital. In this approach, capital is not only a stock of resources available for production, but it is a process that 
indicates the constant renewal and the productive use of this stock. To sum up, knowledge-capital is fed by modern or more ancient approaches of knowledge creation, coordination and diffusion.

Knowledge-capital also aims to integrate the value creation process - which can take, for instance, the form of the production and diffusion of a new machine. The aim of value creation determines the integration of information in the knowledge stock, the combination of information and knowledge, the codification of tacit knowledge and the diffusion of knowledge. With this particular focus on the aim - the value creation process - we also reintegrate in the analysis the tensions linked to the relations of power existing between firms of different sizes and strengths and that particularly occur in the current context of constitution of the knowledge-capital.

\section{Absorptive capacity and open innovation strategies: two main concepts describing the for- mation of the knowledge-capital}

The most recent developments insist on the absorptive capacity and the role of external knowledge and notably on the way firms capture external information in their environment to transform it in their own knowledge. Knowledge production and innovation are thus considered as collective processes and are built within complex innovation networks (Laperche et al. 2008, 2010).

\section{Dynamic capabilities and absorptive capacity}

The literature on the management of innovation (evolutionist theories and more globally resource-based theories) has emphasized the role of dynamic capabilities. The capabilities to develop and renew the specific resources and assets gathered into organizational routines are named 'dynamic capabilities' by Teece et al. (1997). They refer to 'the firm's ability to integrate, build and reconfigure internal and external competences to address rapidly changing environment' (ibid, p. 516). These capabilities may concern the creation of new knowledge or the abandonment of certain activities which are no more profitable.

Among these, 'absorptive capacity' is central in our understanding of knowledgecapital formation, being a prerequisite for its formation. Absorptive capacity was firstly defined by Cohen and Levinthal (1990) as the ability of a firm to recognize the value of new, external information, assimilate it and apply it to commercial ends. Some authors have redefined the concept through the distinction between a potential absorptive capacity and a realized absorptive capacity and identified four dimensions: acquire, assimilate, transform and exploit (Zahra and George 2002).

The literature of absorptive capacity mainly deals with its management as well as its impacts on innovation and on business performance. It is considered as an essential capacity to build competitive advantages over competitors in a context of growing open innovation. In an open innovation process, a firm builds up its knowledge-capital through dynamic knowledge management of its 'knowledge capacities' which Lichtenthaler and Lichtenthaler (2009) define as a firm's critical capabilities of managing internal and external knowledge: inventive, absorptive, transformative, connective, innovative and desorptive capacities. These six capacities are linked through three knowledge processes - knowledge exploration, retention and exploitation - performed either internally or externally. The combination of these capacities used by firms can explain their difference in knowledge trajectories, alliance strategies, organizational configurations and innovation performance. 


\section{Towards open innovation}

The management of innovation activities within firms has been changing over time. The first research and development (R\&D) laboratories were developed within big companies at the end of the nineteenth century and at the beginning of the twentieth century (Liebig in Germany, General Electric in the USA), and then became a major component of their organization. During the twentieth century, the innovation activities of firms were supported by the States which, in the Organisation for Economic Co-operation and Development (OECD) countries, accounted for more than 70\% of gross domestic expenditures on R\&D (GERD) up to the end of the 1970s (30\% on average today). The innovation model was qualified as 'linear': the stages of R\&D were performed successively and at different places (basic research was executed in universities and in research centres, and applied research and technological development within enterprises).

At the early 1980s, when the mass production and consumption model reached its limits, innovation has become the engine of competition between firms implementing global strategies. This period is also characterized by the development of the 'open innovation' paradigm which means that 'valuable ideas can come from inside or outside the company and can go to market from inside or outside the company as well' (Chesbrough 2003, p. 47). According to the author, the development of this model is linked to several changes: a growing mobility of highly skilled workers, the growing presence of venture companies, new possibilities offered to market internal ideas and the increasing capabilities of external suppliers. In this model of open innovation, the creation of knowledge and the whole innovation process proceeds through feedbacks between R\&D, design, production and commercialization. In this chain-linked model (Kline and Rosenberg 1986), the genesis of innovation results from systemic links between knowledge and the market. The open innovation strategies put forward the growing importance of networks, within which the knowledge-capital is built.

The tendency towards the collective constitution of knowledge-capital is gaining ground in the context of economic crisis and particularly in large companies (Laperche et al. 2011). As a matter of fact, collaborative research gives firms the possibility to reduce the cost and risk of innovation development. At the same time, it provides new opportunities for them to renew their supply, finding new technological paths and thus opening new markets. Companies collaborate at all stages of the innovation process (from design to development of new goods and services) and with multiple partners. The objectives (viewed here from the large companies' points of view) are diverse as shown in Table 1.

The open innovation approach is complementary to the research on the systemic nature of innovation processes (Huizingh 2011). Since the term has been coined by Chesbrough 2003, the analysis on collaborative innovation with the 'open' approach defines three processes of open innovation (Chesbrough 2003; Gassmann and Enkel 2004; Chesbrough and Crowther 2006; Lichtenthaler 2008a; Van De Vrande et al. 2009):

1. The first is known as inbound or outside-in open innovation which refers to the exploration and the integration of external resources for internal knowledge development. The inbound process can be further broken down to four paths: technology scouting, horizontal technology collaboration, vertical technology collaboration and technology sourcing (Parida et al. 2012). 
Table 1 Partners of large industrial firms, forms and objectives of collaborations

\begin{tabular}{|c|c|c|}
\hline $\begin{array}{l}\text { Type of } \\
\text { partners }\end{array}$ & Forms of collaboration & Objectives of the firm \\
\hline \multirow{4}{*}{$\begin{array}{l}\text { Academic } \\
\text { research }\end{array}$} & Research programmes & \multirow{2}{*}{$\begin{array}{l}\text { Access to an anticipated vision of the technological } \\
\text { evolution and to new knowledge }\end{array}$} \\
\hline & $\begin{array}{l}\text { International and European } \\
\text { tenders }\end{array}$ & \\
\hline & $\begin{array}{l}\text { Researcher mobility and PhD } \\
\text { funding }\end{array}$ & \multirow[t]{2}{*}{ Reduction of the risk and the cost of upstream research } \\
\hline & Licences & \\
\hline \multirow{2}{*}{$\begin{array}{l}\text { Clients/ } \\
\text { suppliers }\end{array}$} & \multirow{2}{*}{$\begin{array}{l}\text { Alliances (with or without capital } \\
\text { participation) }\end{array}$} & Applied research and co-development of products \\
\hline & & $\begin{array}{l}\text { Reduction of the risk and the cost of product } \\
\text { development }\end{array}$ \\
\hline \multirow[t]{3}{*}{ Competitors } & Joint ventures & Conception of future technologies \\
\hline & \multirow{2}{*}{$\begin{array}{l}\text { International and European } \\
\text { research programmes }\end{array}$} & Pre-competitive research \\
\hline & & $\begin{array}{l}\text { Reduction of the risk and the cost of pre-competitive } \\
\text { research }\end{array}$ \\
\hline \multirow{4}{*}{$\begin{array}{l}\text { Small } \\
\text { innovative } \\
\text { firms }\end{array}$} & \multirow{2}{*}{$\begin{array}{l}\text { Financing, spin-off and } \\
\text { acquisition of start-up }\end{array}$} & Access to very specialized competences \\
\hline & & Technological watch \\
\hline & $\begin{array}{l}\text { Cooperation agreements within } \\
\text { clusters }\end{array}$ & \multirow[t]{2}{*}{ Reduction of the risk and the cost of development } \\
\hline & $\begin{array}{l}\text { European and national research } \\
\text { programmes }\end{array}$ & \\
\hline
\end{tabular}

Source: Laperche and Lefebvre (2011).

2. The second process is known as outbound or inside-out open innovation process that exploits externally the technology capacities through various paths of commercialization: intellectual property licensing, technology multiplying or spin-offs. It is often accompanied by the development of a corporate innovation ecosystem (see, for example, the analysis of Rohrbeck et al. (2009) on the innovation ecosystem built by Deutsche Telekom or the case of IBM Corporate Venture Capital).

3. The coupled process which mixes the outside-in and inside-out processes while dealing with different partners engaged in the same $R \& D$ project.

The degree of openness of companies to outside resources of innovation also appears to be linked to the product life cycle. According to Laursen and Salter (2006), at the beginning of the product life cycle where technology is at an immature state, firms need to depend on a small number of knowledge holders. With the technology becoming more and more mature, they can scan in large scale for technologies and combine various sources for internal knowledge development. Moreover, innovative firms are more keen on using open innovation approach than the non-innovative ones (Huang and Rice 2009; Esbjerg et al. 2012).

The empirical research on absorptive capacity and open innovation capacity has mainly emphasized the behaviour and performance of large companies (Lee et al. 2010; Spithoven et al. 2010; Parida et al. 2012). However, many recent works have focused on SMEs. We study them in the next section.

\section{The knowledge-capital of SMEs}

To study and try to characterize the knowledge-capital of SMEs, we rely on the literature on absorptive capacity and open innovation, considered above as an important current analytic concepts to study a firm's knowledge-capital. 


\section{What is the absorptive capacity of SMEs?}

While being a multidimensional concept, the measure of absorptive capacity has remained mainly based on $R \& D$ proxies, that is to say $R \& D$ inputs (notably $R \& D$ intensity) and outputs (especially patents), even if some recent works try to improve this measure by including new criteria (Flatten et al. 2011). In this perspective, the 'Innovation Index' of the European Commission measures the innovation efforts by the $R \& D$ and non-R\&D investments linked to the firms' innovation activities, the in-house and collaboration efforts between innovative SMEs and public-private research collaboration and the generation of IPR as a throughput in the innovation process (including PCT applications, community trademarks and community designs). To a larger extent, some researchers also use knowledge management and organizational responsiveness as criteria (Liao et al. 2003; Som et al. 2013).

Although the measure of such qualitative factors requires specific empirical qualitative research, traditional indicators give us some insights into the way SMEs perform in terms of absorptive capacity. Due to their weaker human and financial resources (compared to large companies), SMEs represent only a fraction of the business $R \& D$ and patent filing in the countries of OECD. For example, in 2009, SMEs (with 10 to 249 employees) account for $16.8 \%$ of the total business R\&D expenditure in the USA, $27.6 \%$ in the Netherlands and $21.6 \%$ in France (with 1 to 249 employees). In terms of patent filing, among the OECD countries and within the period of 2005 to 2007, young firms of less than 5 years only represent $14 \%$ of patent filings in the USA, $3 \%$ in the Netherlands and 7\% in France. Only Norway seems to be an exception where in 2009, the SMEs with 10 to 249 employees represented $50.5 \%$ of the total business R\&D and around $22 \%$ of patent filings. ${ }^{\mathrm{a}}$

The issue that whether the absorptive capacity differs according to the firm's size does not seem to catch the interest of researchers. More generally, they study the relation between the absorptive capacity and the 'innovativeness' of firms (whatever their size). Three observations can be drawn: First, regardless of sector and size, the absorptive capacity depends on the minimum threshold size of the research team and the cognitive limits of firms (Pavitt 1998). Second, the absorptive capacity also implies that firms need to know where to find new knowledge and how to assimilate it. Here again, regardless of their size, firms who search widely and deeply are likely to be more innovative. However, the benefits of openness will increase to a point from which any additional search will become unproductive (Laursen and Salter 2006). Third, the absorptive capacity is path dependent, which means that the previous experience and knowledge of an individual firm can influence its use of new knowledge. Hence, firms can increase their ability to exploit external knowledge by stimulating internal knowledge sharing (Schmidt 2005).

Empirical research mostly focuses on the absorptive capacity of SMEs in two aspects: the role of absorptive capacity in the enhancement of SMEs' performance and the determinants of absorptive capacity of SMEs. On the one hand, absorptive capacity has a positive impact on an SME's organizational responsiveness to its environment (Liao et al. 2003). Absorptive capacity can help an existing SME to upgrade its innovation capacity. Somfy, a French mechanic SME, reinvents through integrating new knowledge into its internal learning processes ${ }^{\mathrm{b}}$. On the other hand, the internal management of knowledge of an SME plays a determining role on its absorptive capacity. The 
management of knowledge within SMEs will influence the formation of their absorptive capacity in three ways: the organizational knowledge including skills, knowledge and experiences processed by the firm which impacts the accumulative ability; the organizational routine on which the innovation trajectory depends; and the social integration mechanism which determines the ways that knowledge is diffused and shared (Vega-Jurado et al. 2008). Based on these observations, we can find that more specifically, two elements - one internal and other external - can influence the capacities of SMEs to exploit new knowledge developed outside the firm as well as prior related knowledge within the boundary of the firm. On the one hand, the number and the quality of R\&D personnel of SMEs can have a direct impact on the internal capacity of SMEs to absorb the knowledge acquired and to create new ones. Thus, in order to access and to exploit the knowledge of outside partners, SMEs need to have qualified $R \& D$ personnel and to continuously invest in human resources (Muscio 2007). On the other hand, as the absorptive capacity is also considered as a pre-condition to open innovation, technology intermediaries play an important role to help SMEs build up their ability to cope with the knowledge searching and exploitation during the inbound open innovation process (Kodama 2008; Spithoven et al. 2010).

\section{SMEs' open innovation strategies}

Small businesses are traditionally less active than large companies in innovative activity, in the production of internal resources and in the access to external ones. In Europe, 9.5\% of innovative SMEs cooperate with other partners. Cooperation is higher in the leading innovative countries (Denmark, Finland, Germany, Sweden, Switzerland and the UK) than in other countries (European Commission 2013).

The research on open innovation mostly deals with large companies, even if an increasing number of papers put forward the positive aspects of implementing open innovation strategy for SMEs (Gassmann and Keupp 2007; Lichtenthaler 2008a, b; Van de Vrande et al. 2009). The most innovative SMEs are implementing open innovation strategies, as it is the case in biotechnology (Gassmann and Keupp 2007). For them, commercializing their technologies is one of their core competencies and provides a means of rapid growth. They privilege flexible forms, and their main aims are to access markets and to improve the marketing of their products, even if access to new knowledge is also a stated objective. Moreover, empirical studies led in Germany and the Netherlands (Lichtenthaler 2008a, b; Van de Vrande et al. 2009) show that mediumsized but also smaller businesses in industrial or service sectors are more and more open to cooperation, in search for external sources of knowledge. The latest data shows that the collaboration of European innovating SMEs is growing at an annual rate of $7.8 \%$ and becomes a driving force of the EU innovation performance (European Commission 2013).

For SMEs, the reasons for relying more on external sources of knowledge are the same as for larger companies. The competition based on innovation intensifies, and the product and technology development process accelerates. It thus becomes more and more difficult for SMEs to develop new product and technology by themselves (Bianchi et al. 2010). Globalization is identified as another force that pushes SMEs to transform their business models in order to increase their innovativeness (Narula 2004). Some SMEs build their knowledge base gradually through incremental or disruptive 
innovation from the domestic market. Others take a more radical approach and build innovation capacities that allow them to target the international market directly (Lee et al. 2012). The open innovation approach thus allows SMEs to build up knowledgecapital by adopting external technology (Grönlund et al. 2010; Lichtenthaler 2008b) or through combining the external technology and competence with existing internal research and innovation capacities (Christensen et al. 2005; Kogut 2000; Lichtenthaler 2008a).

In terms of the management of innovation, SMEs use differently the open innovation approach from large companies (Chesbrough and Crowther 2006; Lichtenthaler 2008a; Parida et al. 2012). Due to their natural limitations in terms of financial resources and technological capability linked to their small size, SMEs use less structured innovation strategies and are often specialized on one family of knowledge. For example, in France, Huet and Lazaric (2008) showed that cooperation remains marginal within SMEs and when such cooperation occurs, it concerns companies having a similarity of skills (or a low cognitive distance) and of absorptive capacity. In general, SMEs more frequently use collaboration and the inbound open innovation process while large companies have more collaborative partners and different channels of open innovation (Vanhaverbeke et al. 2012; Parida et al. 2012). The inter-organizational network or technology intermediaries are potential knowledge pools where SMEs can seek new technologies for radical as well as incremental innovation.

SMEs are confronted with managerial and organizational difficulties, with problems of efficiency and synergies between marketing and R\&D (Bughin and Jacques 1994) and with limited technical information and know-how which constrain their innovation capacities (Muller 2001). Hence, SMEs more and more rely on innovation networks to build up their knowledge-capital. As a consequence, there is a growing concern on the structure and the governance of research and innovation consortia of small and/or medium-sized firms (Lambert and Schaeffer 2010; Levy et al. 2012; BearingPoint France SAS, Erdyn, Technopolis Group-ITD 2012; Gardet and Fraiha 2012). Public policy has a significant impact on the relational pattern of collaborative innovation of firms. While a large sectoral heterogeneity among actors can lead to a lower probability of networking, the presence of specialized intermediaries increases the collaboration, notably between firms and universities (Caloffi et al. 2013).

Indeed, relations with universities or other public technology facilities represent also an important source of knowledge to SMEs. However, interactions between SMEs and universities are subjected to national differences. In the UK, SMEs consider the universities as sources of radical innovation and engage more in a horizontal collaborative relationship with them. In comparison, relationships between US firms and universities are more vertical supply chain-linked as the latter are considered as one of the many suppliers of technologies (Huggins et al. 2011).

Collaborations between small firms and large companies also exist. In that case, the small business participates to the large company's strategy of knowledge-capital formation. All these forms of cooperation often take place within clusters, defined by Porter (1998) as 'geographic concentrations of interconnected companies and institutions in a particular field'. Within clusters, SMEs may benefit from proximity which create an 'industrial atmosphere', source of knowledge externalities and collective learning that may contribute to the development of their absorptive capacity and thus of their 
knowledge-capital. However, other forms of networks may exist, based on other forms of proximity (organizational, social, cultural, cognitive and institutional forms) (see Boschma 2005; Boutillier and Uzunidis 2010) which may also enhance the SMEs' knowledge acquisition (Davenport 2005).

When the geographic concentration of activities only concerns small companies (like in some industrial districts) (Becattini et al. 2009), these small firms can reinforce their knowledge-capital by sharing and constituting new knowledge and value it collectively or individually through innovation. This kind of networks may help small companies face the competition of large companies through specialization on specific segments of markets (as in craft industry for example). Through geographic clusters and other types of networks gathering SMEs, these ones may also specialize in technological niches (specific components for example) that will eventually help them integrate the value chains of large companies. This latter point arouses some specific questions, related to the stakes, benefits and limits of the participation of small firms in the innovative networks built by large companies, which are particularly studied in the next section.

\section{The place of SMEs in the knowledge-capital of large companies Roles of SMEs in large companies' knowledge-capital}

If we focus more specifically on the relationship between small and large companies, we shall put forward the contribution of small businesses (and more specifically the most innovative ones) in the large companies' knowledge-capital development and use. Indeed, as shown in Table 1, large companies constitute innovation networks made of relationships with various actors. We also put forward in this part the main forms of relationships between small and large companies.

Inter-firm technological exchanges and the dynamics complementarities between large and small firms play complementary roles in technological innovation (Rothwell and Dodgson 1991). Innovative small firms play key roles in innovative networks built by large companies, which we can divide into two main roles: (1) the contribution to large companies' knowledge-capital formation and continuous enrichment and (2) the valuation of the knowledge-capital, through notably the commercialization of technologies developed within the innovation networks.

Regarding the first role, groups implement intelligence strategies and have access through their cooperation with SMEs - to innovative technologies and complementary skills outside their usual fields of research which they integrate into their knowledgecapital (inbound open innovation). However, this role of SMEs also depends on their stage of development. For example, according to Lambert and Schaeffer (2010), within the automotive sector, start-ups are outside innovation opportunities that the large company will like to capture while the more mature SMEs act as an integrated part of a project where they can bring in specific know-how. Still, included in this first role, cooperation with small businesses also allows large companies to produce a product at a lower cost by increasing the speed of development.

Regarding the second role, SMEs are also channels for large companies to monetize their technology (outbound open innovation) as the latter increasingly adopts a 'use it or lose it' IP strategy. For example, Isobionics, a Dutch biotechnology start-up, is developed based on technology owned by DSM, a large Dutch chemical company (Vanhaverbeke et al. 2012, p. 78). New technology-based firms (NTBFs) are another 
channel for big firms to commercialize patent or technology which may not fit with the corporate strategy or structure, such as companies spun-out from Xerox's Palo Alto Research Center (including 3Com, Adobe, etc.) by the individuals who left the company with technologies developed inside (Tidd and Bessant 2009). In some other cases, large companies use small firms as a 'window' of new technologies in the emerging sectors such as CAD or biotechnology (Roberts and Berry 1985).

To create links with SMEs, large firms use combined methods such as licensing, $R \& D$ or manufacturing subcontracting, collaborative development, joint ventures, spinouts or corporate venture (Rothwell 1989). Indeed, one of the main forms of relations between small and large firms in innovative activity is that of investment in start-ups through venture capital. Corporate venture has grown strongly in the USA during the 1990s and has spread in Europe before being held back by the bursting of the bubble of the net economy in 2001: many of these investments were oriented towards the achievement of a financial gain. They have endured and still exist today (MacMillan et al. 2008). The investors' objectives are various: large companies, when investing in small businesses, not only look for financial gain but also aim to develop, at a lower cost and with fewer risks, new technologies or seek to consolidate the group's activities (through, for example, the dissemination of a standard) (Chesbrough 2002). This can be done through the acquisition of the start-up at the end of the financing period. In that case, the development cost of the acquired firm (and of its technology) has been shared between several investors, or it may also be achieved through the signature of partnership agreements (including licensing). In other words, for groups, investment in venture capital fits into their financial and technological strategy.

Many examples show the continuous interest of large companies in corporate venture programmes. For example, IBM seeks VC-backed companies for new technology and business models as well as new emerging markets (Brown 2012). Saint-Gobain created in 2007 the NOVA External Venture programme to develop strategic partnerships with innovative SMEs in the fields of energy, services for the construction industry and cleantech. The aim is to facilitate the development of start-ups through licenses, joint development agreements, production or distribution agreements, joint ventures and minority investment - or any combination of these. PSA is developing a technology and service monitoring strategy particularly by technology co-investment funds which aims to support start-ups (EcoMobility Venture). Schneider Electric has a common venture capital fund (Aster Capital) with Alstom for the same aim and in the field of energy efficiency (Laperche and Picard 2013).

Relations between groups and small innovative companies can also take pure partnership forms. Currently, some of these partnership programmes are initiated by companies themselves as demonstrated by outsourcing strategies. Big companies have been induced to concentrate on their core business, which by the way increased outsourcing strategies. Many small companies are thus the outcome of these outsourcing strategies. For example, Deutsch Telekom spins out new firms as an alternative path to commercialize R\&D results while looks for new venture opportunities (Rohrbeck et al. 2009). However, the relationship between the parent company and the small business often continues, through partnership agreements.

Partnership agreements may also be signed in the framework of a national or international research programme, or within clusters, evoked in the 'SMEs' open innovation 
strategies' section. As a matter of fact, in industrial countries, industrial policy has shifted from reducing costs of production to the increase of managerial know-how and the intensification of links between firms. Such cooperation may concern SMEs notably through not only local production systems but also the relations between SMEs, large companies and public research (Viale and Etzkowitz 2010). In France, for example, large companies often play crucial roles in the governance of clusters, as it is the case for Valeo, Saint-Gobain, Renault or PSA, where they initiate R\&D programmes involving SMEs (Laperche and Lefebvre 2011). Then, it is through research programmes at national and European levels or through clusters that SMEs are encouraged to work with large groups.

\section{Limits of the integration of SMEs in large companies' knowledge-capital}

For an SME, taking part to the innovation network built by a larger company may be an essential support for its technological product of process development since the small business may benefit from the financial, technological and marketing support of the big company. Taking part to an innovation network is thus a powerful means to be profitable and even sometimes to survive.

However, this type of collaboration may be difficult due to the unequal and asymmetrical power relation between the two partners. In case of conflicts, for example, dealing with intellectual property rights of products developed in common, the small business may be disadvantaged, due to its weaker resources. The 'cognitive distance' (Nooteboom 2000) between the small and big companies may also hinder the learning processes and be counterproductive. Due to their lack of negotiation power, collaboration with large companies to develop and commercialize new technology will increase the dependence of SMEs to generate value from their technology and thus limit the yield of their intellectual property (Katila et al. 2008; Vanhaverbeke et al. 2012).

A study on French competitiveness clusters questions the clustering effect of innovation networks mainly led by big firms on the capacity building of SMEs. Sectorbased clusters allow SMEs to be better integrated to innovation networks and hence to access and share knowledge with large companies. However, the lack of clearly defined offers in terms of competence, cooperative process, access to market and funding (Bassot et al. 2008), as well as the lack of coordination and coaching of SMEs engaged in R\&D projects (BearingPoint France SAS, Erdyn, Technopolis Group-ITD 2012), limits the benefit that the SMEs can draw from collaborating with large companies. Moreover, the ability of SMEs to participate to several projects simultaneously is limited regardless of the nature of the projects in terms of the intensity of research or the sources of funding (Levy et al. 2012).

Finally, cooperation sometimes leads to the acquisition of the small business by the large company. That means the disappearance of the small company. The integration of the small business within the bigger one may also lead to a lower creativity due to the different habits and routines of the two organizations. This is for this reason that General Electric, which massively bought small companies in the 1990s, abandoned the systematic acquisition strategy, and in case they integrate small companies in their huge organization, they try to let them some autonomy to preserve their creativity (Laperche and Lefebvre 2011). 
To reduce the concentration of knowledge and the vertical dependence to big companies, SMEs can eventually develop a horizontal network and share knowledge inside the same industry or between different industries. Lambert and Schaeffer (2010) used the case of the French competitiveness clusters in the electronic sector to show that by boosting its internal capacity to provide made-to-order technological solutions, an SME can become an essential actor in the production of knowledge needed for breakthrough innovation within a trans-industrial network. In other words, it is through the reinforcement of the knowledge-capital (developing absorption capacity and implementing open innovation strategies) that SMEs will be able to increase their negotiation power within innovation networks.

\section{Conclusions}

Even if small companies compared to larger ones record weaker performances in terms of absorptive capacity and implementation of open innovation strategy, they may increase their knowledge-capital through the combination of their strengths. This can give them the possibility to face the competition of big companies and specialize in specific niches. The most innovative SMEs also play important roles in the knowledgecapital of large companies. They indeed participate to its formation and continuous enrichment, and they also contribute to its valorization, through notably the commercialization of technologies developed within innovation networks. However, the participation of SMEs to innovation networks is not a way paved of roses since their negotiation power is often hindered by their weak resources.

For their own innovation strategy, as well as for the innovation performance in general, the reinforcement of SMEs' knowledge-capital is thus a priority. The research on the absorptive capacity of firms as a matter of fact underscores the importance of the internal capacity notably the R\&D human resources of an individual firm to assimilate external knowledge. The intended public policy to support the innovation network built by firms can change the relational pattern of the SMEs, pushing them to collaborate in a stable way. This implies that the public policy should enhance the support to technology transfer and absorption and facilitate the development of technology intermediaries, adapted to the needs of SMEs. However, public measures to support innovation collaboration between SMEs and external technology providers such as universities should not be uniformed and need to adapt to the practice of knowledge management of local firms (Liu 2013).

Our study was based on a literature review which gave us the possibility to identify the main conceptual categories useful to study and characterize SMEs' ability to build their own knowledge-capital and to join (and benefit from) innovation networks constituted by large corporations. It gave us useful keys of comprehension of the performance and behaviour of SMEs in terms of absorptive capacity and open innovation strategies. However, some interesting questions could be further developed in order to define adapted public policies aimed at reinforcing the knowledge-capital of SMEs. For example, the studies dealing with the absorptive capacity and open innovation strategies of SMEs handle distinctly high-tech industries and traditional industries. In consequence, we cannot compare the way that SMEs in different industry sectors benefit from open innovation process to build their internal capital. Studying empirically the strategies of small firms' knowledge-capital formation and valorization, as well as their 
place and role in innovation networks, will therefore be another step in our research. Another question which could be further developed is the management of SMEs' intellectual property rights within the innovation network. We may consider that the issue of the protection of small firms' knowledge assets is a key incentive (but currently still a limit) for their participation to innovation networks. Current researches on the subject mainly deal with large companies as well as the specific cases of small high-tech businesses or patent trolls. This is therefore another related work that will ensue from this paper.

\section{Endnotes}

${ }^{a}$ The data on business $R \& D$ expenditure is extracted from the 'Business enterprise RD expenditure by size class and by source of funds' of OECD.StatExtracts on 14 April 2013 and then calculated by the authors. The original data is on million national currencies.

${ }^{\mathrm{b}}$ The case study was presented at the conference INNOVATION 2013 organized by INSA Lyon and Research Network on Innovation, in Lyon, on 10 June 2013.

Competing interests

The authors declare that they have no competing interests.

\section{Authors' contributions}

Blandine Laperche particularly focused on the definition and explanation of the knowledge-capital concept. Zeting Liu mainly focused on the empirical review of SMEs and the constitution of their knowledge-capital. Both authors read and approved the final manuscript.

Received: 23 September 2013 Accepted: 4 October 2013

Published: 16 Dec 2013

\section{References}

Bassot, P, Ezvan, C, \& Koeltz, J. (2008). Les pôles de compétitivité: un vrai levier pour l'innovation des PME? Réalité industrielles, 2008, 95-102.

BearingPoint France SAS, Erdyn, Technopolis Group-ITD. (2012). Etude portant sur l'évaluation des pôles de compétitivité. Rapport global. DGCIS-DATAR: Paris.

Becattini, G, Bellandi, M, \& De Propris, L (Eds.). (2009). A handbook on industrial districts. Cheltenham: Edward Elgar.

Bianchi, M, Orto, SC, Frattini, F, \& Vercesi, P. (2010). Enabling open innovation in small- and medium-sized enterprises: how to find alternative applications for your technologies. R\&D Management, 40(4), 414-430.

Boschma, RA. (2005). Proximity and innovation: a critical assessment. Regional Studies, 39(1), 61-74.

Boutillier, S, \& Uzunidis, D. (2010). The innovative milieu as a driving force of entrepreneurship. In B Laperche, P Sommers, \& D Uzunidis (Eds.), Innovation networks and clusters. The knowledge backbone (pp. 135-158). Brussels: Peter Lang.

Brown, N. (2012). Understanding entrepreneurship: open innovation and corporate venture capital, Young Company Finance Scotland, presentation, August 2012.

Bughin, J, \& Jacques, JM. (1994). Managerial efficiency and the Schumpeterian link between size, market structure and innovation revisited. Research Policy, 23(6), 653-659.

Caloffi, A, Rossi, F, \& Russo, M. (2013). Does participation in innovation networks improve firms' relational abilities? Evidence from a regional policy framework. DRUID, Copenhagen Business School, Department of Industrial Economics and Strategy/Aalborg University, Department of Business Studies: DRUID Working Papers 13-07.

Chesbrough, H. (2002). Making sense of corporate venture capital. Harv Bus Rev, 80, 4-11.

Chesbrough, H. (2003). Open innovation: the new imperative for creating and profiting from technology. Boston: Harvard Business School Press.

Chesbrough, H, \& Crowther, AK. (2006). Beyond high tech: early adopters of open innovation in other industries. $R \& D$ Management, 36(3), 229-236.

Christensen, JF, Olesen, MH, \& Kjær, JS. (2005). The industrial dynamics of open innovation: evidence from the transformation of consumer electronics. Research Policy, 34(10), 1553-1559.

Cohen, WM, \& Levinthal, DA. (1990). Absorptive capacity: a new perspective on learning and innovation. Administrative Science Quarterly, 35(1), 128-152.

Davenport, S. (2005). Exploring the role of proximity in SME knowledge-acquisition. Research Policy, 34(5), 683-701.

Dosi, G, Nelson, RR, \& Winter, N. (2000). The nature and dynamics of organizational capabilities. Oxford: Oxford University Press.

Esbjerg, L, Knudsen, MP, \& Søndergaard, HA. (2012). Diffusion of open innovation practices in Danish SMEs. Ledelse \& Erhvervsøkonomi, 02, 27-39.

European Commission. (2013). Innovation Union Scoreboard 2013. Brussels: European Commission.

Flatten, TC, Engelen, A, Zahra, SA, \& Brettel, M. (2011). A measure of absorptive capacity: scale development and validation. European Management Journal, 29, 98-116. 
Galbraith, JK. (1967). The new industrial state. Boston: Houghton Mifflin.

Gardet, E, \& Fraiha, S. (2012). Coordination Modes established by the Hub Firm of an Innovation Network: The Case of a SME Bearer. Journal of Small Business Management, 50(2), 216-238.

Gassmann, O, \& Enkel, E. (2004). Towards a theory of open innovation: three core process archetypes, R\&D Management Conference (RADMA), conference paper, Lisbon, 6 July 2004.

Gassmann, O, \& Keupp, M. (2007). The competitive advantage of early and rapidly internationalising SMEs in the biotechnology industry: a knowledge based view. Journal of World Business, 42(3), 350-366. Special Issue: The Early and Rapid Internationalization of the Firm.

Grönlund, J, Rönnberg Sjödin, D, \& Frishammar, J. (2010). Open innovation and the stage-gate process: a revised model for new product development. Calif Manage Rev, 52(3), 106-131.

Huang, F, \& Rice, J. (2009). The role of absorptive capability in facilitating 'open innovation' outcomes: a study of Australian SMEs in the manufacturing sector. International Journal of Innovation Management, 13(2), 201-220.

Huet, F, \& Lazaric, N. (2008). Capacités d'absorption et d'interaction: une etude de la coopération dans les PME françaises. Revue d'économie industrielle, 121, 65-84.

Huggins, R, Prokop, D, Johnston, A, Steffenson, R, \& Clifton, N. (2011). Small firm-university knowledge networks: evidence from the UK and the US. Stanford University, California: Triple Helix IX Conference, conference paper. 11-14 July 2011.

Huizingh, EKRE. (2011). Open innovation: state of the art and future perspectives. Technovation, 31(1), 2-9.

Katila, R, Rosenberger, JD, \& Eisenhardt, KM. (2008). Swimming with sharks: technology ventures, defense mechanisms and corporate relationships. Adm Sci Q, 53, 295-332.

Kline, SJ, \& Rosenberg, N. (1986). An overview of innovation. In R Landau \& N Rosenberg (Eds.), The positive sum strategy (pp. 275-305). Washington, DC: Academy of Engineering Press.

Kodama, T. (2008). The role of intermediation and absorptive capacity in facilitating university-industry linkages-an empirical study of TAMA in Japan. Research Policy, 37, 1224-1240.

Kogut, B. (2000). The Network as Knowledge: Generative Rules and the Emergence of Structure. Strategic Management Journal, 21, 405-425.

Lambert, G, \& Schaeffer, V. (2010). A new role for small business in innovation networks: an industrial perspective. International Journal of Entrepreneurship \& Small Business, 9(1), 1-19.

Laperche, B. (2007). Knowledge-capital and innovation in multinational corporations. Journal of Technology and Globalisation, 3(1), 24-41.

Laperche, B, \& Lefebvre, G. (2011). Les petites entreprises dans la dynamique d'innovation ouverte des groupes industriels. In A Hamdouch, S Reboud, \& C Tanguy (Eds.), PME, dynamiques entrepreneuriales et innovation (pp. 279-301). Brussels: Peter Lang.

Laperche, B, \& Picard, F. (2013). Environmental constraints, product-service systems development: learning from manufacturing firms in the French context. Journal of Cleaner Production, 53, 118-128.

Laperche, B, Uzunidis, D, \& Von Tunzelmann, N (Eds.). (2008). The genesis of innovation, systemic linkages between knowledge and the market. Cheltenham: Edward Elgar.

Laperche, B, Sommers, P, \& Uzunidis, D (Eds.). (2010). Innovation networks and clusters. The knowledge backbone. Brussels: Peter Lang.

Laperche, B, Lefebvre, G, \& Langlet, D. (2011). Innovation strategies of industrial groups in the global crisis: rationalisation and new paths. Technological Forecasting and Social Change, 78(8), 1319-1331.

Laursen, K, \& Salter, A. (2006). Open for innovation: the role of openness in explaining innovation performance among U.K. manufacturing firms. Strategic Management Journal, 27(2), 131-150.

Lee, S, Park, G, Yoon, B, \& Park, J. (2010). Open innovation in SMEs-an intermediated network model. Research Policy, 39, 290-300.

Lee, Y, Shin, J, \& Park, Y. (2012). The changing pattern of SME's innovativeness through business model globalization. Technological Forecasting \& Social Change, 79, 832-842

Levy, R, Hussler, C, \& Triboulet, P. (2012). The evolution of the French collaborative network of innovation: towards clustering? Copenhagen: DRUID Conference. 19-21 June 2012.

Liao, J, Welsh, H, \& Stoica, M. (2003). Organizational absorptive capacity and responsiveness: an empirical investigation of growth-oriented SMEs. Entrepreneurship Theory and Practice, 28(1), 63-85.

Lichtenthaler, U. (2008a). Open innovation in practice: an analysis of strategic approaches to technology transactions. IEEE Transaction, 55(1), 148-157.

Lichtenthaler, U. (2008b). Opening up strategic technology planning: extended roadmaps and functional markets. Management Decision, 46(1), 77-91.

Lichtenthaler, U, \& Lichtenthaler, E. (2009). A capability-based framework for open innovation: complementing absorptive capacity. Journal of Management Studies, 46(8), 1315-1338.

Liu, Z. (2013). Le système national d'innovation et la Policy mix de l'innovation en France: une revue historique. In S Boutillier, F Djellal, \& D Uzunidis (Eds.), Innovation. Anticiper et agir. Brussels: Peter Lang.

MacMillan, I, Roberts, E, Livada, V, \& Wang, A. (2008). Corporate venture capital (CVC). Seeking innovation and strategic growth. Recent patterns in CVC mission, structure, and investment. Washington D.C.: National Institute of Standards and Technology, U.S. Department of Commerce.

Marx, K. (1977). Grundrisse. Anthropos: T. II. Paris.

Muller, E. (2001). Innovation interactions between knowledge-intensive business services and small and medium-sized enterprises. Technology, Innovation and Policy, 11, 27-47.

Muscio, A. (2007). The impact of absorptive capacity on SMEs' collaboration. Economics of Innovation and New Technology, 8, 653-668.

Narula, R. (2004). R\&D collaboration by SMEs: new opportunities and limitations in the face of globalisation. Technovation, 25, 153-161.

Nelson, RR, \& Winter, SG. (1982). An evolutionary theory of economic change. Cambridge: Harvard University Press. Nooteboom, B. (2000). Learning by interaction, absorptive capacity, cognitive distance and governance. Journal of Management and Governance, 4, 69-92. 
Parida, V, Westerberg, M, \& Frishammar, J. (2012). Inbound open innovation activities in high-tech SMEs: the impact on innovation performance. Journal of Small Business Management, 50(2), 283-309.

Pavitt, K. (1998). Technologies, products \& organisation in the innovating firm: what Adam Smith tells us and Joseph Schumpeter doesn't. Industrial and Corporate Change, 7, 433-452

Penrose, ET. (1959). The theory of the growth of the firm. Oxford: Blackwell.

Porter, M. (1998). Clusters and the new economics of competition. Harv Bus Rev, 76, 77-90.

Roberts, EB, \& Berry, CA. (1985). Entering new business: Selecting strategies for success. Sloan Management Review, 26(3), 3-17.

Rohrbeck, R, Hölzle, K, \& Gemünden, HG. (2009). Opening up for competitive advantage - how Deutsche Telekom creates an open innovation ecosystem. R\&D Management, 39(4), 420-430.

Rothwell, R. (1989). SMF, inter-firm relationships and technological change. Entrepreneurship and Regional Development, 1, 275-291.

Rothwell, R, \& Dodgson, M. (1991). External linkages and innovation in small and medium-sized enterprises. R\&D Management, 21(2), 125-137.

Say, JB. (1996). Catéchisme D'économie politique, in cours D'économie politique Et autres essais. Paris: GF Flammarion.

Schmidt, T. (2005). Absorptive capacity: one size fits all? Firm-level analysis of absorptive capacity for different kinds of knowledge. ZEW Discussion Paper No. 05-72. Mannheim: ZEW.

Schumpeter, JA. (1950). Capitalism, socialism and democracy. New York: Harper \& Row.

Schumpeter, JA. (1983). The theory of economic development. New Brunswick: Transaction Publishers.

Smith, A. (1976). Recherches sur la nature et les causes de la richesse Des nations. Paris: Coll. Folio essais, Gallimard.

Solow, R. (1957). Technical change and the aggregate production function. Review of Economics and Statistics, $39,313-320$.

Som, O, Kirner, E, \& Jager, A. (2013). Absorptive capacity on non-R\&D intensive firms in the German manufacturing industry. Barcelona: 35th DRUID Celebration Conference, conference paper. 17-19 June 2013.

Spithoven, A, Clarysse, B, \& Knockaert, M. (2010). Building absorptive capacity to organise inbound open innovation in traditional industries. Technovation, 30, 130-141.

Teece, DJ, Pisano, G, \& Shuen, A. (1997). Dynamic capabilities and strategic management. Strategic Management Journal, 18(7), 509-533.

Tidd, J, \& Bessant, J. (2009). Managing innovation. Integrating technological, market and organizational change. Chichester: Wiley.

Van de Vrande, V, de Jong, JP, Vanhaverbeke, W, \& de Rochemont, M. (2009). Open innovation in SMEs: trends, motives and management challenges. Technovation, 29, 423-437.

Vanhaverbeke, W, Vermeersch, I, \& De Zutter, S. (2012). Open innovation in SMEs: how can small companies and start-ups benefit from open innovation strategies? Research report. Gent: Vlerick Leuven Gent Management School.

Vega-Jurado, J, Gutierrez-Gracia, A, \& Fernandez-de-Lucio, I. (2008). Analyzing the determinants of firm's absorptive capacity. R\&D Management, 38(4), 392-405.

Viale, R, \& Etzkowitz, H. (2010). The capitalization of knowledge: a triple helix of university-industry-government. Cheltenham: Edward Elgar.

Zahra, SA, \& George, G. (2002). Absorptive capacity: a review, a reconceptualization and extension. Academy of Management Review, 27(2), 185-203.

10.1186/2192-5372-2-21

Cite this article as: Laperche and Liu: SMEs and knowledge-capital formation in innovation networks: a review of literature. Journal of Innovation and Entrepreneurship 2013, 2:21

\section{Submit your manuscript to a SpringerOpen ${ }^{\circ}$ journal and benefit from:}

- Convenient online submission

- Rigorous peer review

- Immediate publication on acceptance

- Open access: articles freely available online

- High visibility within the field

- Retaining the copyright to your article

Submit your next manuscript at $\boldsymbol{~ s p r i n g e r o p e n . c o m ~}$ 